\title{
INFLUENCE OF SOLAR RADIATION \\ AND MODULE TEMPERATURE ON SOLAR MODULE PERFORMANCE
}

\section{Israa F. Eldehn*, Mustafa, M.M.**, Elnono, M.**, Hegazi, A.***}

\begin{abstract}
Photovoltaic module $(P V)$ performance decreases with the increase of module temperature. While, it increases with increasing solar radiation intensity. PV system is used to convert solar energy into electric power then it will be connected with a pumping system (DC motor and centrifugal pump) to run trickle irrigation system for small scale areas in Inshas. Solar panels temperature and solar radiation intensity play a big part in the photovoltaic conversion process. Since solar cells are semiconductors, they are very sensitive to temperature. The characteristic power curve is affected significantly by the module temperature. In this paper each of voltage, module efficiency and the output power of $P V$ module depend on solar panels temperature at different values $\left(30^{\circ}-40^{\circ}\right.$ $\left.50^{\circ} \mathrm{C}\right)$, solar radiation intensity ranged at (900-1000) $\mathrm{W} / \mathrm{m}^{2}$ and $\mathrm{PV}$ module (Polycrystalline $240 W_{P}$ ). During the operation of the PV, module efficiency reached to be around $14.5 \%$ which is $P V$ conversion efficient for solar radiation to electricity. The electrical efficiency will decrease with the increase of solar panels temperature of the PV module.
\end{abstract}

Keywords: Photovoltaic, Solar radiation, Module temperature.

\section{INTRODUCTION}

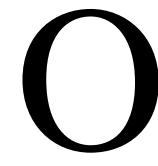

$\mathrm{n}$ this paper, it can show solar radiation and module temperature influencing solar generator for a standalone photovoltaic pumping (PVP) system. PVP consists of PV generator modules (4modules*240 $\mathrm{W}_{\mathrm{p}}$ ), DC motor $(700 \mathrm{~W})$ and centrifugal pump $(700 \mathrm{~W})$. For obtained data; solar panels temperature do not remain constant for the whole daytime, but they fluctuated noticeably.

\footnotetext{
*Agriculture Specialist at Nuclear Res. Center, Atomic Energy Authority. ** Prof. of Ag. Eng. Dept., Fac. Ag., A. Shams Univ.

*** Lecture of soil \& water Res. Dept., Nuclear Res. Center, Atomic Energy Auth.
} 
Investigations were done to represent the influence of the solar panels temperature variation on the performances of the optimized system, for temperature data obtained ranged at $\left(20^{\circ}-30^{\circ}-40^{\circ}-50^{\circ} \mathrm{C}\right)$ and solar radiation intensity $\left(R_{s}\right)$ ranged at $(900-1000) \mathrm{W} / \mathrm{m}^{2}$. Output power represented in (current and voltage) and module efficiency were affected by the variations of solar panels temperature. It has been concluded these performances are degraded once the solar panels temperature increases. Solar water pumping system is based on a PV that converts solar radiation into electricity to pump water for irrigation. It consists of three major components: the PV-generator (a number of PV modules connected in series or parallel in a mounting structure), a motor (DC or AC) and a pump (centrifugal or submersible). The PV panels are connected to a motor (DC or AC) which converts electrical energy supplied by the PV panel into mechanical energy which is then converted to hydraulic energy by the pump. The capacity of a solar pumping system (SPS) to pump water is a function of three main variables : pressure, flow and power. A photovoltaic (PV) system is able to supply electric energy to a given load by directly converting solar energy through the photovoltaic effect by using semiconductor materials. The system structure is very flexible. PV modules are the main building blocks; these can be arranged into arrays to increase electric energy production. Normally additional equipment is necessary in order to transform electric energy into mechanical energy represented in pumping system (DC motor and the pump). Nelson et al., (2003) mentioned that increases in temperature reduce the band gap of a semiconductor, thereby effecting most of the semiconductor material parameters. The decrease in the band gap of a semiconductor with increasing temperature can be viewed as increasing the energy of the electrons in the material. The parameter most affected by an increase in temperature is the open circuit voltage. Temperature coefficient indicates how much will be the decrement in power output if PV module temperature varies from STC. Schwingshackl et al., (2013) stated that since solar cells are semiconductors, they are very sensitive to temperature. The characteristic power curve is affected significantly by the module temperature. The open-circuit voltage decreases significantly with increasing PV module 
temperature (values are up to $-0.45 \% / \mathrm{K}$ for crystalline silicon) whereas the short circuit current increases only slightly. The solar cell efficiency is usually measured under standard test conditions (STC), with PV cell temperature of $25^{\circ} \mathrm{C}$, irradiance of $1000 \mathrm{~W} / \mathrm{m}^{2}$ and air mass (1.5). These conditions are rarely met at outdoor installations. The PV cell temperature, which can be assumed to be the same as the temperature of the PV module, shows large variability under outdoor conditions. It has therefore an important impact on the solar cell efficiency and thus, on the energy yield. Hamrouni et al., (2008) stated that efficiency of the PV pumping system depends on several climatic factors such as the solar radiation, the ambient temperature and the state of the solar panels (ageing, cleanliness...). Gouws et al., (2012) mentioned that the most important environmental factors are: 1) solar irradiation, 2) meteorological data and 3) air mass and indirect radiation. The factors influencing the performance and efficiency of the PV panel are: 1) the type of PV material used, 2) the tilt angle and azimuth, 3) characteristics of the PV cell, and 4) PV array arrangement (for example, how many modules in the panel are in series and how many panels in the array are in parallel?). Alonso et al., (2004) discussed that module temperature is a parameter that has great influence in the behavior of a PV system, as it modifies system efficiency and output energy. Skoplaki et al., (2009) said that the effect of temperature on the electrical efficiency of a PV cell/module can be traced to the former's influence upon the current, I, and the voltage, $\mathrm{V}$, as the maximum power is given by $\left(\mathrm{P}_{\mathrm{m}}=\mathrm{V}_{\mathrm{m}} * \mathrm{I}_{\mathrm{m}}\right)$. Ebaid et al., (2013) stated that a PV module's power and voltage are related to the temperature of the module's cells. To calculate the power loss, the following Equation (1) is used,

$$
\mathbf{P}_{\mathrm{T}: \text { Loss }}=\mathbf{C}_{\mathbf{P}} * \mathbf{P}_{\text {Max }}\left(\mathbf{T}_{\mathbf{m}}-\mathbf{T}_{\mathbf{m}, \text { ref }}\right)
$$

Where:

$\mathrm{P}_{\mathrm{T} ; \text { loss }}$ : Power loss (W).

$\mathrm{P}_{\max }$ : Maximum rated power of PV module $\left(\mathrm{W}_{\mathrm{p}} / \mathrm{m}^{2}\right)$.

Tm : Average module temperature $\left({ }^{\circ} \mathrm{C}\right)$.

$\mathrm{T}_{\mathrm{m}, \mathrm{ref}}$ : Reference module temperature $\left({ }^{\circ} \mathrm{C}\right)$.

$\mathrm{C}_{\mathrm{P}}$ : Temperature coefficient of maximum power $\left(\% /{ }^{\circ} \mathrm{C}\right)$. 


\section{MATERIALS AND METHODS}

Experiments were carried out in Inshas city that is characterized by sandy soil at Soil and Water Research Department, Nuclear Research Center, Atomic Energy Authority, Egypt. The latitude and longitude of the experiment site are $30^{\circ} 24^{\circ} \mathrm{N}, 31^{\circ} 35^{\circ} \mathrm{E}$, respectively, while the altitude is $20 \mathrm{~m}$ above the sea level. One array consists of 4 modules or panels that are typically interconnected in parallel in order to give a current for a $32 \mathrm{~A}$ and $30 \mathrm{~V}$ to DC motor. For high power requirement, the type used for this experiments is NESL polycrystalline $240 \mathrm{~W}$ (module efficiency 14.5\%), tilt angle was $40^{\circ}$ in for winter season and $30^{\circ}$ for summer tilt from the horizontal. Fig.(1) showed PV modules under study and Table (1) showed solar module electrical datasheet.

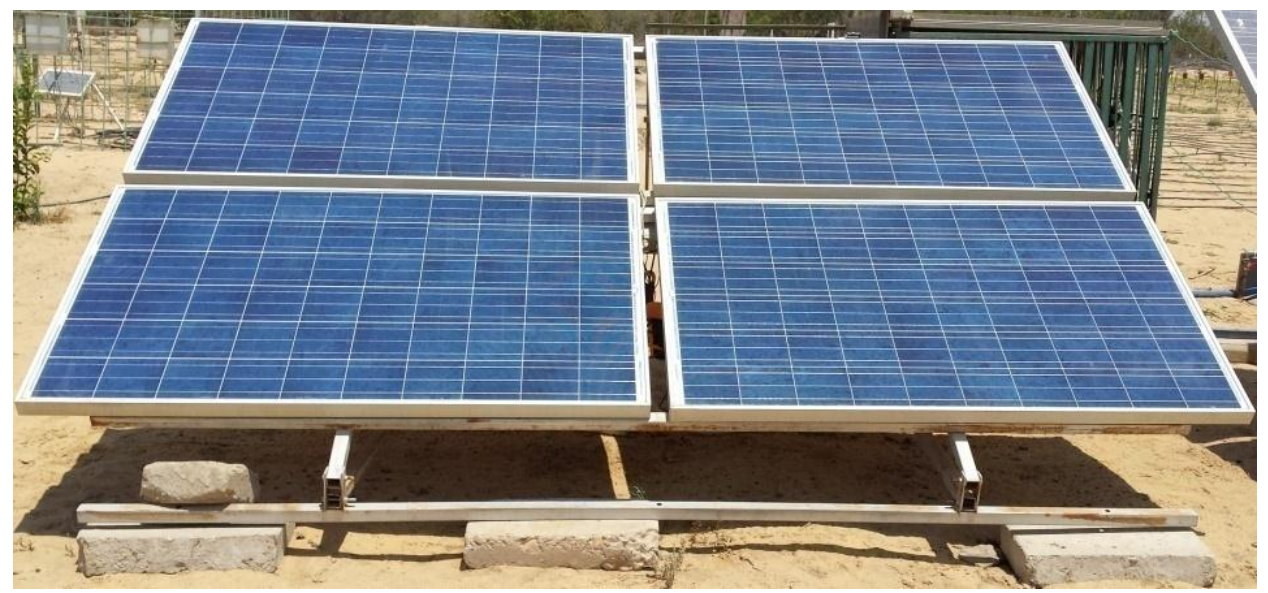

Fig. (1): NESL (PV) polycrystalline $240 \mathrm{~W}$ (4 modules).

NESL DJ-240PA manufacturer gave I-V function of solar insolation for ($25^{\circ}, 0^{\circ}, 25^{\circ}, 50^{\circ}$ and $75^{\circ} \mathrm{C}$ ). However, the $\mathrm{I}-\mathrm{V}$ is a temperature variation dependant. A fixed temperature doesn't exist in practice. I-V curve supplied by manufacturer for a PV module is shown in Fig.(2) and it is clearly seen that the I-V output characteristic of a PV module is highly nonlinear. It behaves as current source for the low voltage zone and as a voltage source in the high voltage zone. The output power in these regions is far below the optimal values which could be generated if the solar array works around the knee of the I-V characteristic. The characterizing rated 
values of an array are the short circuit current, open circuit voltage and maximum power as a function of solar panels temperature and irradiance (solar radiation intensity).

Table (1): PV module electrical datasheet.

\begin{tabular}{|c|c|}
\hline Model & DJ-240PA \\
\hline Peak power & $\mathrm{P}_{\mathrm{mpg}} 240 \mathrm{~W}$ \\
\hline Rated voltage & $\mathrm{V}_{\text {mag }} 29.7 \mathrm{~V}$ \\
\hline Rated current & $\mathrm{I}_{\mathrm{mp}} 8.08 \mathrm{~A}$ \\
\hline Open circuit voltage & $\mathrm{V}_{\text {or. }}, 36.2 \mathrm{~V}$ \\
\hline Short circuit current & $\mathrm{I}_{58} \quad 8.88 \mathrm{~A}$ \\
\hline Max series fuse rating & $15 \mathrm{~A}$ \\
\hline Module efficiency & $14.69 \%$ \\
\hline Max. system Voltage & $1000 \mathrm{~V}, 600 \mathrm{~V}$ \\
\hline \multirow{4}{*}{ Temperature Coefficient } & NOCT (Normal Operating Cell Temperature) $48^{\circ} \mathrm{C} \pm 2^{\circ} \mathrm{C}$ \\
\hline & $\mathrm{P}_{\max }-0.45 \% \mathrm{k}$ \\
\hline & $\begin{array}{ll}\text { oc } & -0.35 \% k\end{array}$ \\
\hline & $\mathrm{I}_{\mathrm{s} \varepsilon} \quad+0.05 \% \mathrm{k}$ \\
\hline
\end{tabular}

STC (standard test condition): irradiance $1000 \mathrm{~W} / \mathrm{m}^{2}$, module temperature $25^{\circ} \mathrm{C}$, air mass $=1.5 \mathrm{G}$. (NESL DJ-240PA)

Measuring tools which were used in experiments are in Fig.(3):

1. Pyranometer to measure solar radiation intensity $\left(\mathrm{W} / \mathrm{m}^{2}\right)$ Calibration Uncertainty: $\pm 5 \%$.

2. Multimeter to measure generator output Voltage (Volt) (accuracy $\pm(0.5 \%+4 \mathrm{~d}))$.

3. Current clamp to measure generator output DC current (Ampere) (accuracy $\pm(1.5 \%+5)$ ).

4. Thermometer type-k to measure the different values of solar panels temperature by using thermocouple $\left({ }^{\circ} \mathrm{c}\right)$. 


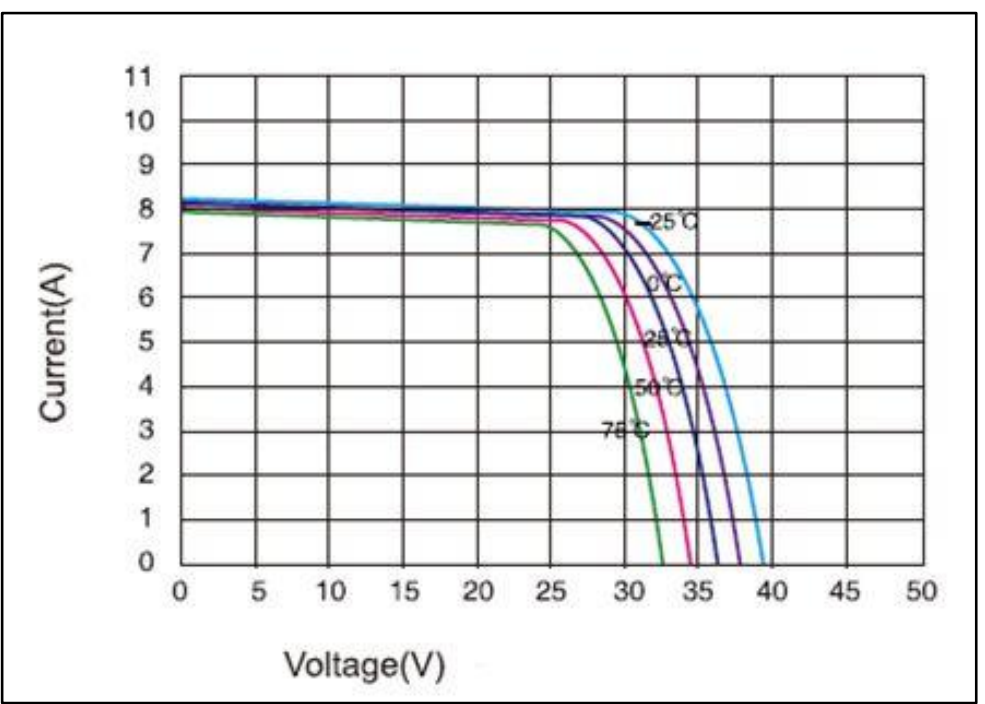

Fig. (2): I-V curve manufacturer, current/voltage characteristics with dependence on irradiance and module temperature. Irradiance $1000 \mathrm{~W} / \mathrm{m}^{2}$ and air mass=1.5 G. (NESL DJ-240PA)

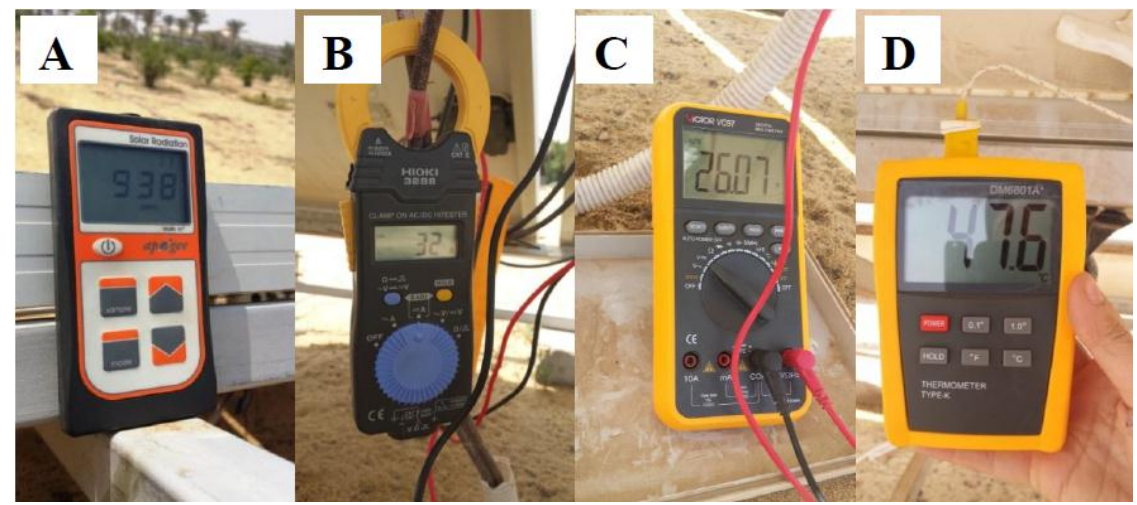

Fig. (3):
(A) Pyranometer.
(B) Current clamp.
(C) Multimeter.
(D) Thermometer type-k.

Electric power consumption was calculated by using Equation (2):

$$
\mathbf{P}_{\mathbf{P V}}=\mathbf{I}_{\mathbf{m p}} * \mathbf{V}_{\mathbf{m p}}
$$

Where :

$\mathrm{P}_{\mathrm{PV}}$ : electric output power peak $(\mathrm{W})$.

$\mathrm{I}_{\mathrm{mp}}$ : maximum power current (amp).

$\mathrm{V}_{\mathrm{mp}}$ : maximum power voltage (volt).

Efficiency of modules ( $\left.\eta_{\mathrm{PV}}\right)$ was calculated using Equation (3): 


$$
\mathbf{n}_{\mathbf{P V}}=\frac{\mathbf{V}_{\mathbf{m p}} * \mathbf{I}_{\mathbf{m p}}}{\mathbf{A}_{\mathbf{P V}} * \mathbf{R}_{\mathbf{S}}}
$$

where:

$\mathrm{A}_{\mathrm{PV}}$ : surface area of the solar array, $\left(\mathrm{m}^{2}\right)$.

$\mathrm{R}_{\mathrm{S}}$ : solar radiation, $\left(\mathrm{W} / \mathrm{m}^{2}\right)$.

$\mathrm{I}_{\mathrm{mp}}$ : maximum power current, (amp).

$\mathrm{V}_{\mathrm{mp}}$ : maximum power voltage, (volt).

\section{RESULTS AND DISCUSSION}

Measurements were performed in order to evaluate the performance of Photovoltaic solar cells system and PV efficiency under conditions of different parameters affecting the performance. Factors under investigations were:

1. Solar panels temperature.

2. Solar radiation intensity.

Solar panels temperature varies daily and seasonally due to meteorological parameters affecting its temperature, such as solar radiation $\left(\mathrm{R}_{\mathrm{S}}\right)$, ambient temperature and wind speed. While the electrical current and voltage are the physical parameters.

Fig. (4) illustrate fluctuation of the output voltage due to the fluctuating solar panels temperature ranged at $\left(20^{\circ}-30^{\circ} \mathrm{C}\right)$. The higher the solar panels temperature the lower output voltage at the solar radiation values from (900-1000) $\mathrm{W} / \mathrm{m}^{2}$. Average voltage was $27.6 \mathrm{~V}$ for the solar panels temperature average of $23.4^{\circ} \mathrm{C}$ at solar radiation average of $950.1 \mathrm{~W} / \mathrm{m}^{2}$.

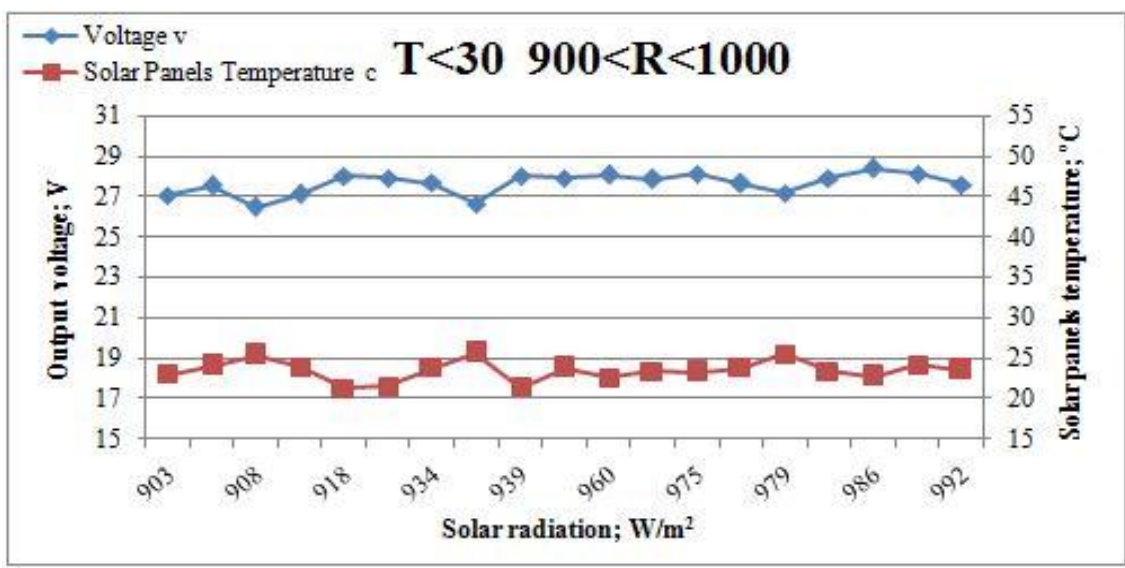

Fig. (4): Performance of voltage and solar panels temperature $\left(\mathrm{T}<30^{\circ} \mathrm{C}\right)$ at different solar radiation intensity values. 
Fig. (5) illustrate fluctuation of the output voltage due to the fluctuating solar panels temperature ranged at $\left(30^{\circ}-40^{\circ} \mathrm{C}\right)$. The higher solar panels temperature the lower output voltage at solar radiation values from (9001000) $\mathrm{W} / \mathrm{m}^{2}$. Average voltage was $27.3 \mathrm{~V}$ for the solar panels temperature average of $34.6^{\circ} \mathrm{C}$ at solar radiation average $941.1 \mathrm{~W} / \mathrm{m}^{2}$.

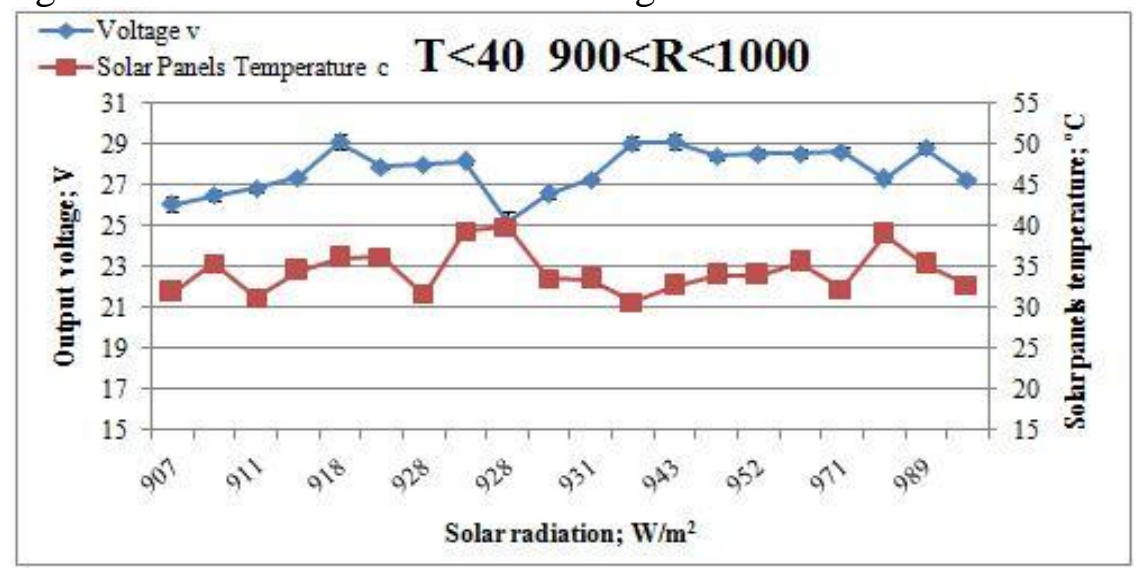

Fig. (5): Performance of voltage and solar panels temperature $\left(\mathrm{T}<40^{\circ} \mathrm{C}\right)$ at different solar radiation intensity values.

Fig. (6) illustrate fluctuation of the output voltage due to the fluctuating solar panels temperature ranged at $\left(40^{\circ}-50^{\circ} \mathrm{C}\right)$. The higher solar panels temperature the lower output voltage at solar radiation values from (9001000) $\mathrm{W} / \mathrm{m}^{2}$. Average voltage was $26.4 \mathrm{~V}$ for the solar panels temperature average of $45.0^{\circ} \mathrm{C}$ at solar radiation average $940.1 \mathrm{~W} / \mathrm{m}^{2}$.

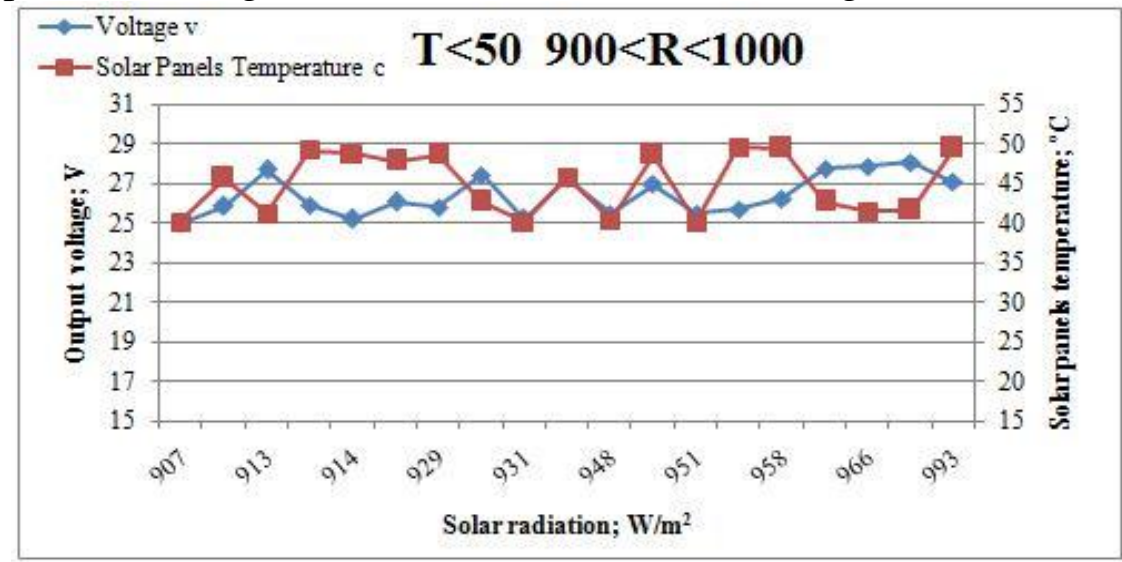

Fig. (6): Performance of voltage and Solar panels temperature $\left(\mathrm{T}<50^{\circ} \mathrm{C}\right)$ at different solar radiation intensity values.

As shown on Fig. (7) the average voltage was $27.6 \mathrm{~V}$ at $23.4^{\circ} \mathrm{C}, 27.3 \mathrm{~V}$ at $34.6^{\circ} \mathrm{C}$ and $26.4 \mathrm{~V}$ at $45.0^{\circ} \mathrm{C}$. 
Manufacturer mentioned that the change of voltage output for every solar panel tempereature degree kelven was $(-0.35 \% \mathrm{~V} / \mathrm{K})$. From data aquired from field measurments; it was $(-0 . r \cdot 1 \% \mathrm{~V} / \mathrm{K})$ solar panels temperature ranged at $\left(34.6-45.0^{\circ} \mathrm{C}\right)$. On the otherhand, it was $(-0 . \cdot 9 \vee \% \mathrm{~V} / \mathrm{K})$ when solar panels temperature ranged from $\left(23.4^{\circ}\right.$ to $\left.34.6^{\circ} \mathrm{C}\right)$.

Fig. (8) illustrate fluctuation of the output power due to the fluctuating solar panels temperature ranged at $\left(20^{\circ}-30^{\circ} \mathrm{C}\right)$. The higher solar panels temperature the lower output power at solar radiation values from (9001000) $\mathrm{W} / \mathrm{m}^{2}$. Average output power was $891.6 \mathrm{~W}$ for the solar panels temperature average of $23.4^{\circ} \mathrm{C}$ at solar radiation average $950.1 \mathrm{~W} / \mathrm{m}^{2}$.

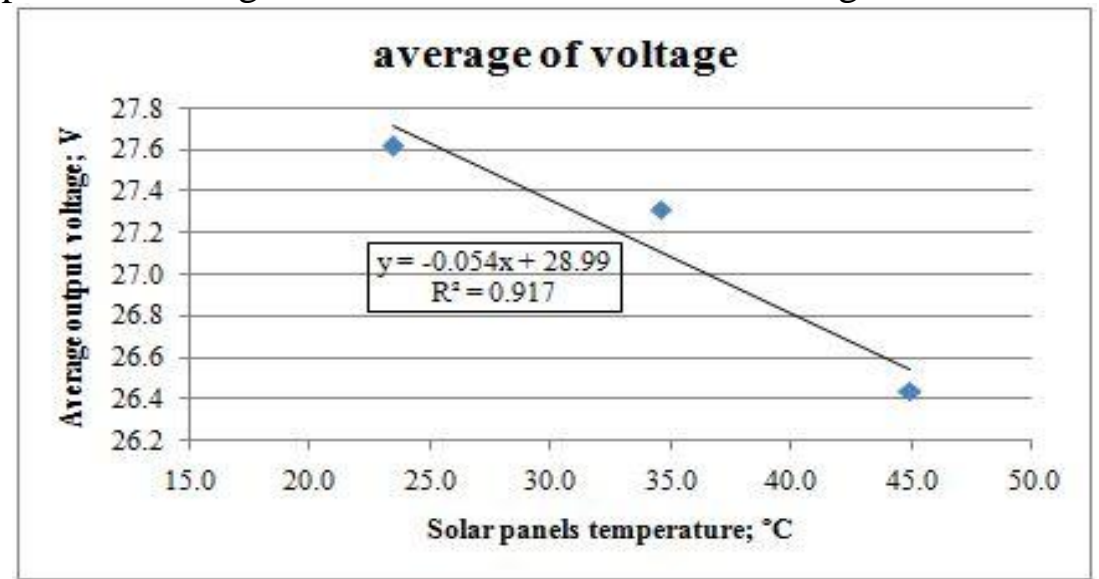

Fig. (7): Average of voltage values at different average values of solar panels temperature.

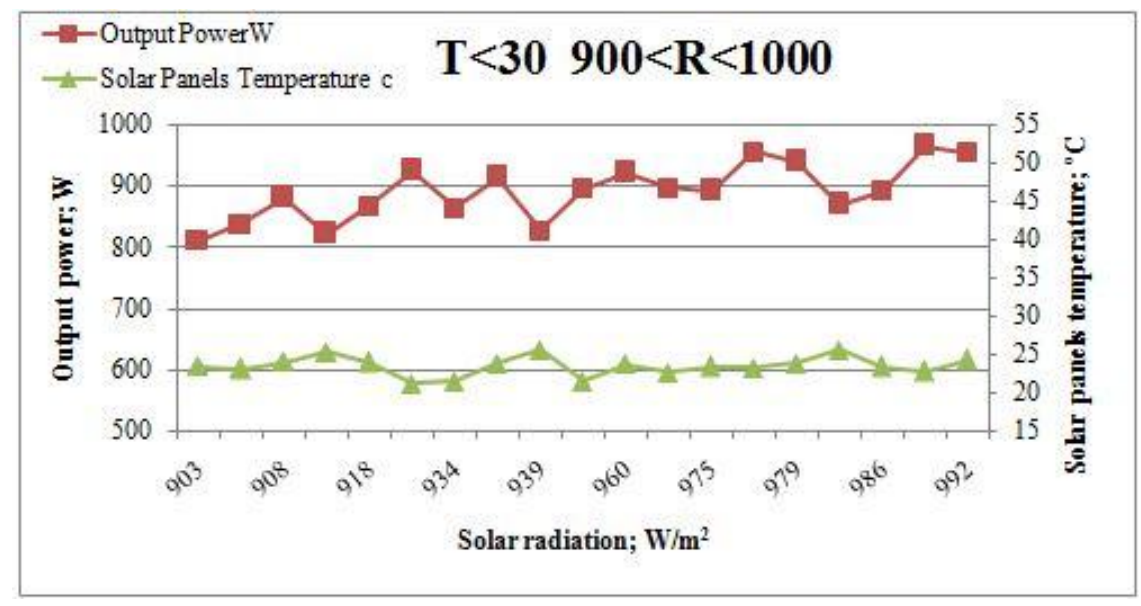

Fig. (8): Performance of output power and solar panels temperature $\left(\mathrm{T}<30^{\circ} \mathrm{C}\right)$ at different solar radiation intensity values. 
Fig. (9) illustrate fluctuation of the output power due to the fluctuating solar panels temperature ranged at $\left(30^{\circ}-40^{\circ} \mathrm{C}\right)$. The higher solar panels temperature the lower output power at solar radiation values from (9001000) $\mathrm{W} / \mathrm{m}^{2}$. Average output power was $868.7 \mathrm{~W}$ for the solar panels temperature average of $34.6^{\circ} \mathrm{C}$ at solar radiation average $941.1 \mathrm{~W} / \mathrm{m}^{2}$.

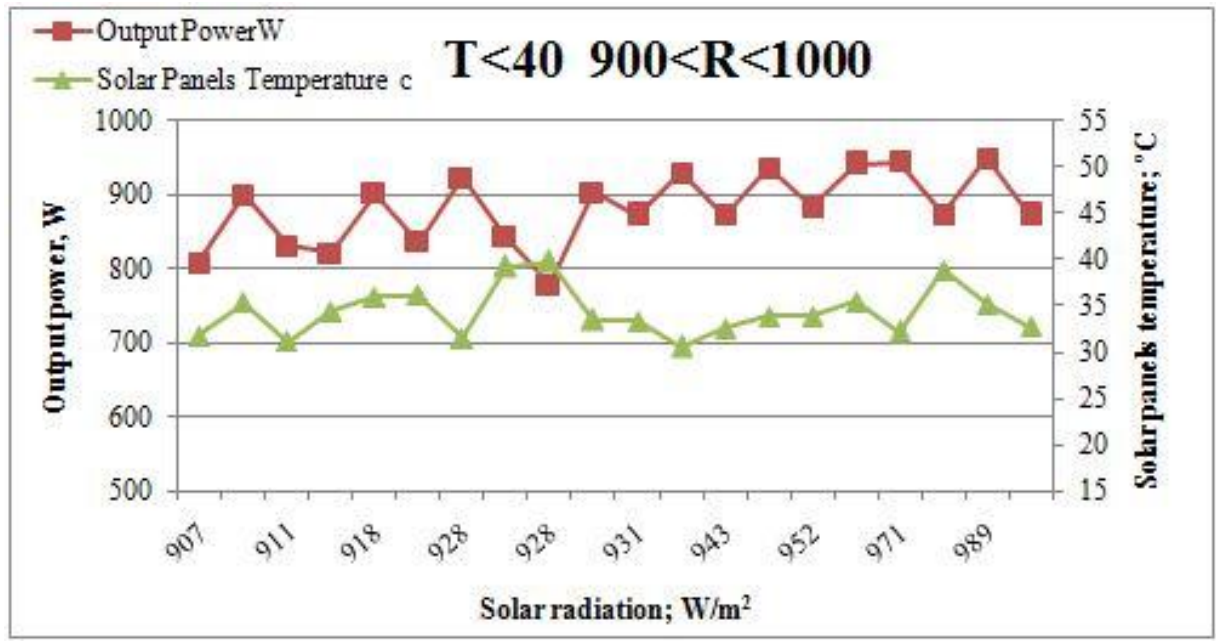

Fig. (9): Performance of output power and solar panels temperature $\left(\mathrm{T}<40^{\circ} \mathrm{C}\right)$ at different solar radiation intensity values.

Fig. (10) illustrate fluctuation of the output power due to the fluctuating solar panels temperature ranged at $\left(40^{\circ}-50^{\circ} \mathrm{C}\right)$. The higher solar panels temperature the lower output power at solar radiation values from (9001000) $\mathrm{W} / \mathrm{m}^{2}$. Average output power was $870.2 \mathrm{~W}$ for the solar panels temperature average of $45.0^{\circ} \mathrm{C}$ at solar radiation average $940.1 \mathrm{~W} / \mathrm{m}^{2}$.

As shown on Fig. (11) the average output power was $891.6 \mathrm{~W}$ at $23.4^{\circ} \mathrm{C}$, 868.7 $\mathrm{W}$ at $34.6^{\circ} \mathrm{C}$ and $870.2 \mathrm{~W}$ at $45.0^{\circ} \mathrm{C}$.

Manufacturer mentioned that the change of output power for every solar panel temperature degree kelven was $(-0.45 \% \mathrm{~W} / \mathrm{K})$. From data aquired from field measurments; it was $(-0.111 \% \mathrm{~W} / \mathrm{K})$ when solar panels temperature ranged from $\left(34.6^{\circ}-45.0^{\circ} \mathrm{C}\right)$. On the otherhand, it was ($0 . r$ $9 \% \mathrm{~W} / \mathrm{K})$ when solar panels temperature ranged from $\left(23.4^{\circ}\right.$ to $34.6^{\circ} \mathrm{C}$ ). 


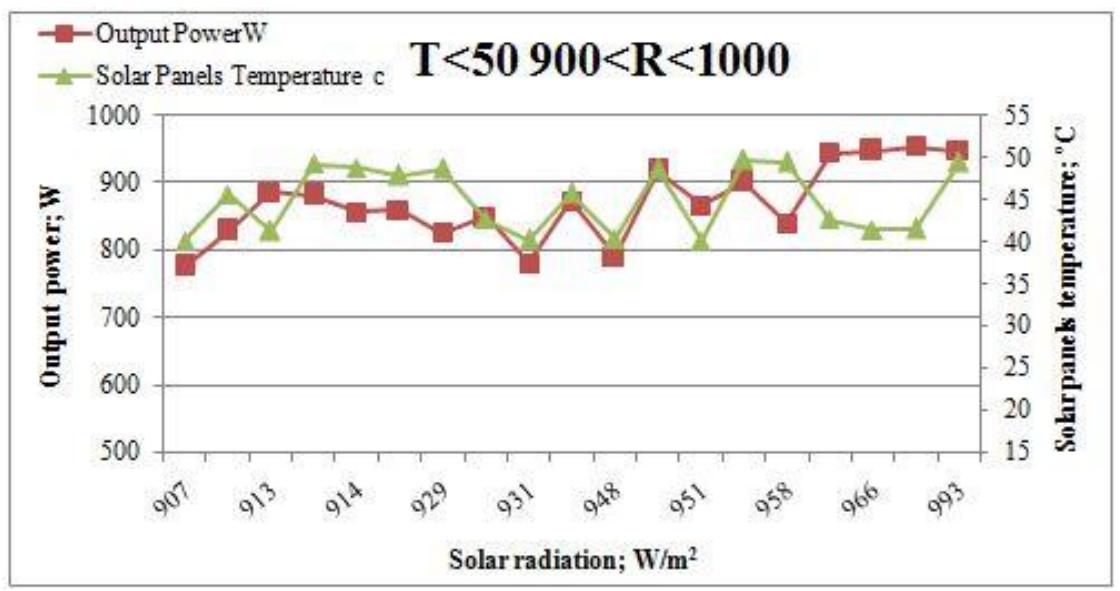

Fig. (10): Performance of output power and solar panels temperature $\left(\mathrm{T}<50^{\circ} \mathrm{C}\right)$ at different solar radiation intensity values.

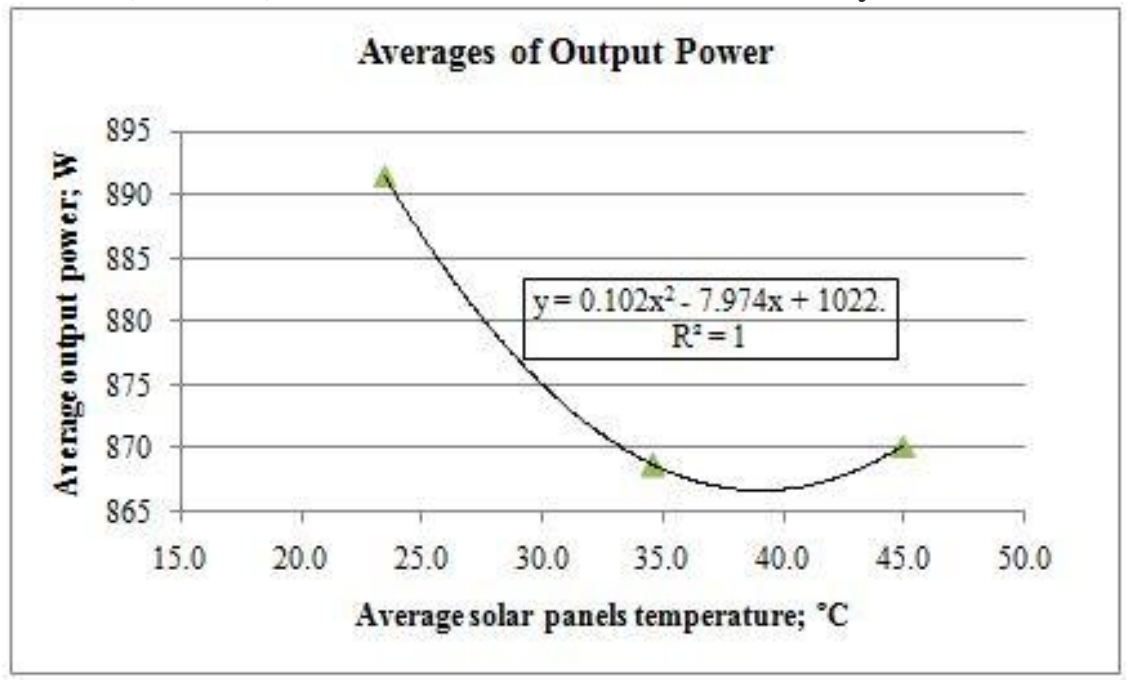

Fig. (11): Average of output power values at different average values of solar panels temperature.

As shown on Fig. (12) the average output power was $891.6 \mathrm{~W}$ at 950.1 $\mathrm{W} / \mathrm{m}^{2}, 868.7 \mathrm{~W}$ at $941.1 \mathrm{~W} / \mathrm{m}^{2}$ and $870.2 \mathrm{~W}$ at $940.2 \mathrm{~W} / \mathrm{m}^{2}$.

From the giving data about the system; it's clear that the system has excess output power to help the system supplement of the motor needed at any conditions such cloudy days, dust accumulation(soiling) and the high panel temperature that helps to have the enough power output for motivating DC motor. 


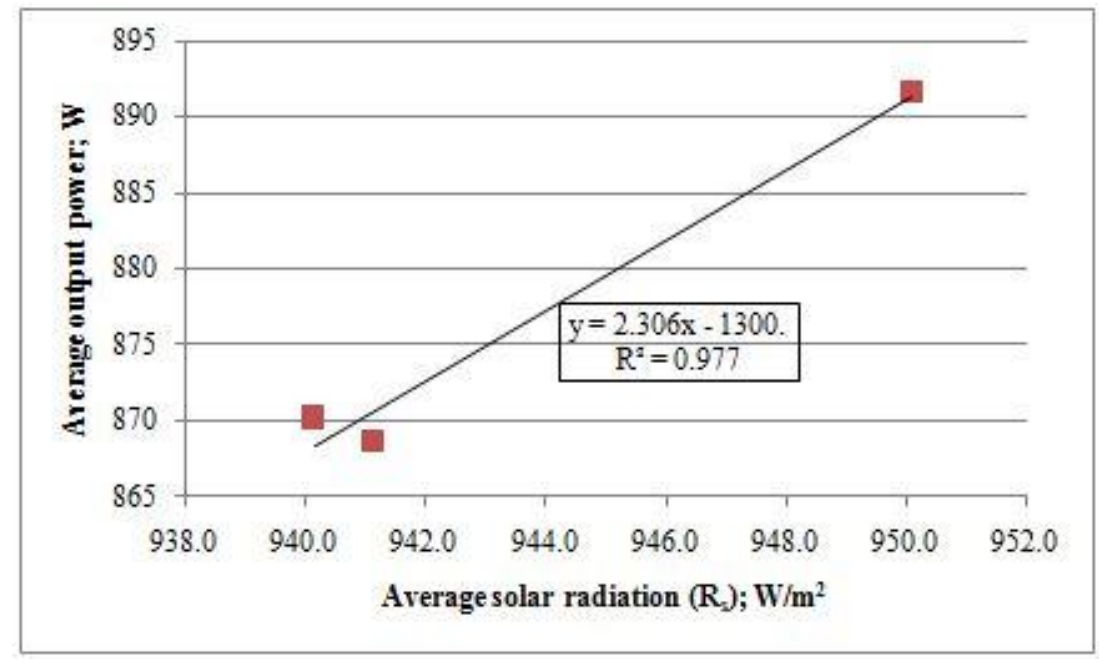

Fig. (12): Average of output power values at different average values of solar radiation.

Fig. (13) illustrate the fluctuation of the module efficiency due to the fluctuating solar panels temperature ranged at $\left(20^{\circ}-30^{\circ} \mathrm{C}\right)$. The higher the solar panels temperature, the lower module efficiency at solar radiation values from (900-1000) W/m². Average module efficiency was $14.36 \%$ for the solar panels temperature average of $23.4{ }^{\circ} \mathrm{C}$ and at solar radiation average of $950.1 \mathrm{~W} / \mathrm{m}^{2}$.

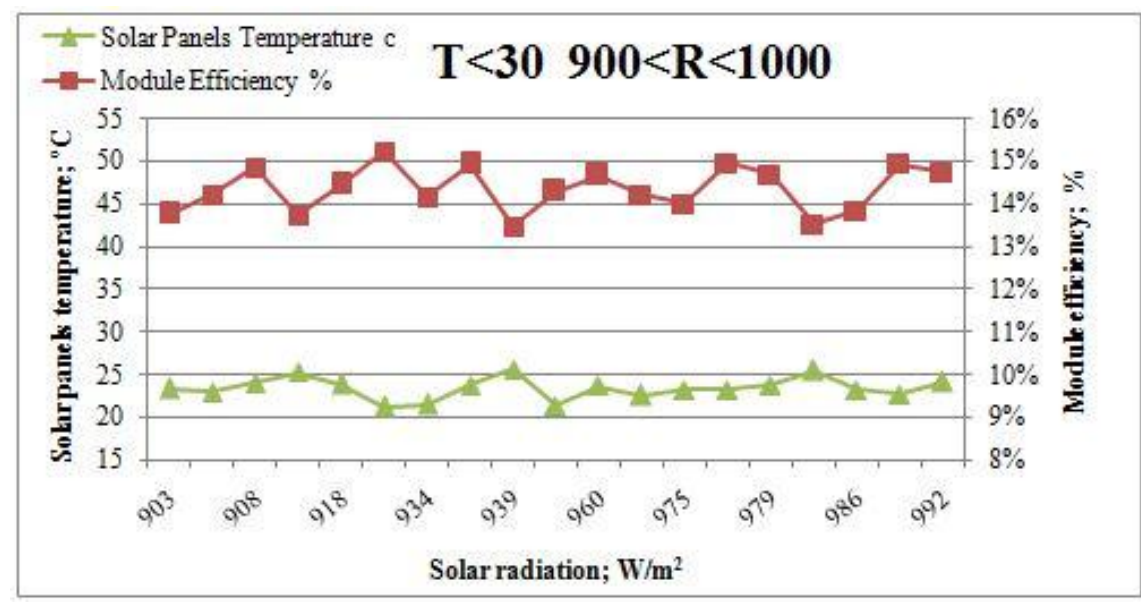

Fig. (13): Module efficiency and solar panels temperature $\left(\mathrm{T}<30^{\circ} \mathrm{C}\right)$ at different solar radiation intensity values. 
Fig. (14) illustrate the fluctuation of the module efficiency due to the fluctuating solar panels temperature ranged at $\left(30^{\circ}-40^{\circ} \mathrm{C}\right)$. The higher the solar panels temperature, the lower module efficiency at solar radiation values from (900-1000) W/m². Average module efficiency was $14.13 \%$ for the solar panels temperature average of $34.6{ }^{\circ} \mathrm{C}$ and at solar radiation average of $941.1 \mathrm{~W} / \mathrm{m}^{2}$.

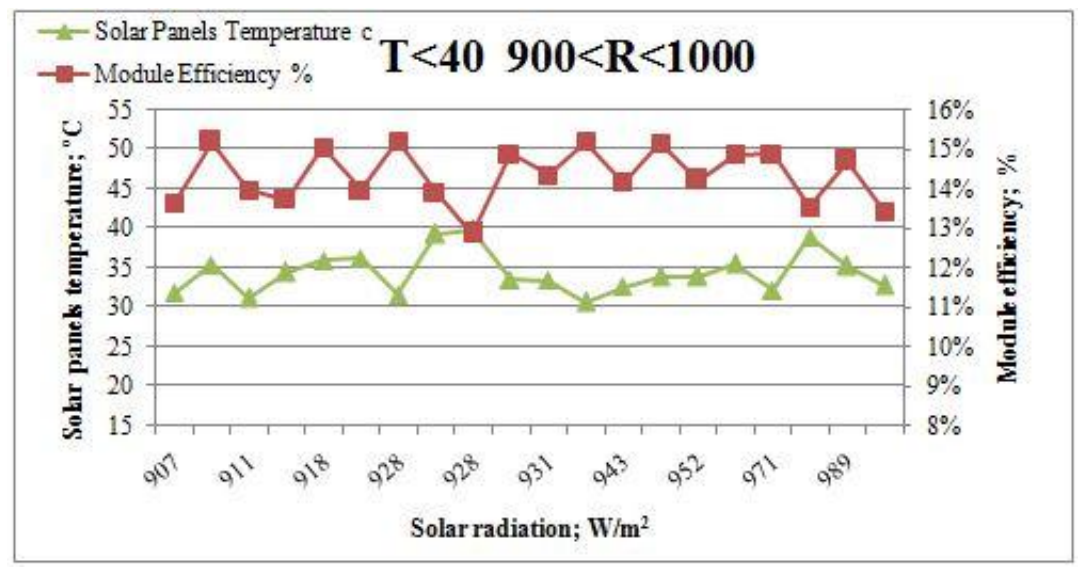

Fig. (14): Module efficiency and solar panels temperature $\left(\mathrm{T}<40^{\circ} \mathrm{C}\right)$ at different solar radiation intensity values.

Fig. (15) illustrate the fluctuation of the module efficiency due to the fluctuating solar panels temperature ranged at $\left(40^{\circ}-50^{\circ} \mathrm{C}\right)$. The higher the solar panels temperature, the lower module efficiency at solar radiation values from (900-1000) W/m ${ }^{2}$. Average module efficiency was $14.16 \%$ for the solar panels temperature average of $45.0^{\circ} \mathrm{C}$ and at solar radiation average of $940.1 \mathrm{~W} / \mathrm{m}^{2}$.

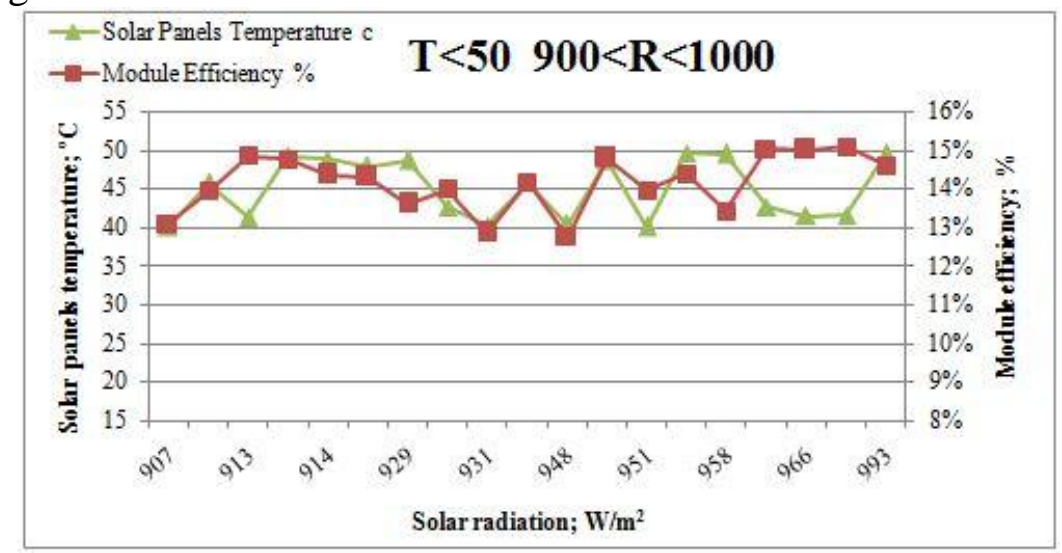

Fig. (15): Module efficiency and solar panels temperature $\left(\mathrm{T}<50^{\circ} \mathrm{C}\right)$ at different solar radiation intensity values. 
As shown on Fig. (16) the average module efficiency was $14.36 \%$ at $23.4{ }^{\circ} \mathrm{C}, 14.13 \%$ at $34.6{ }^{\circ} \mathrm{C}$ and $14.16 \%$ at $45.0{ }^{\circ} \mathrm{C}$.

Manufacturer mentioned that the module efficiency was $14.69 \%$. From data equired from field measurments; it was $14.36 \%$ at $23.4{ }^{\circ} \mathrm{C}, 14.13 \%$ at $34.6{ }^{\circ} \mathrm{C}$ and $14.16 \%$ at $45.0{ }^{\circ} \mathrm{C}$.

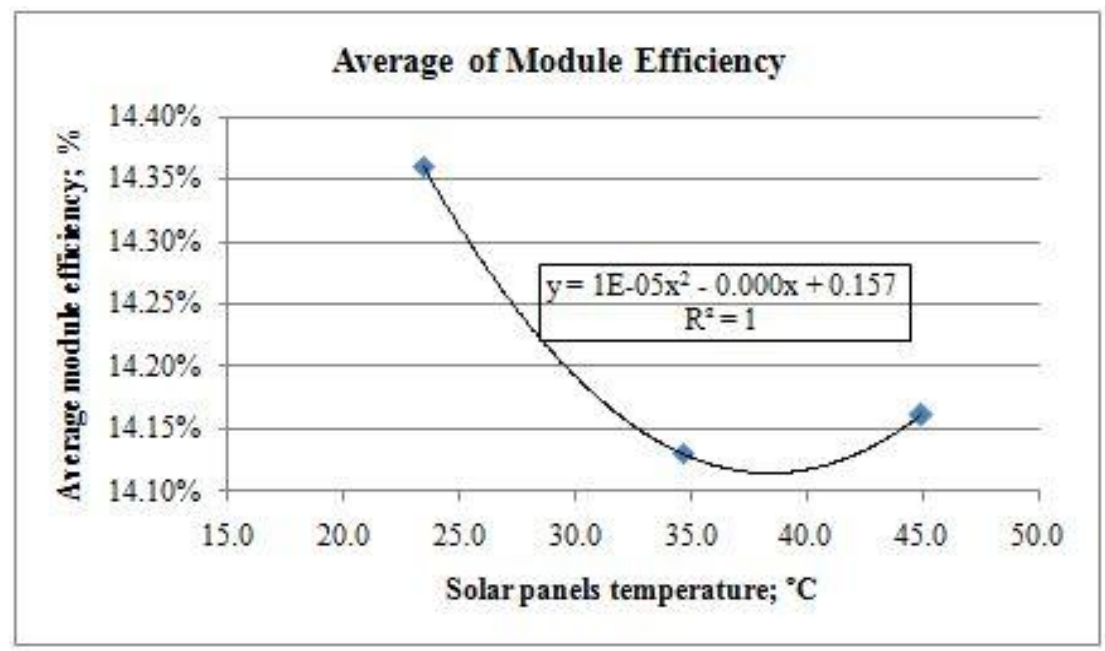

Fig. (16): Average of module efficiency values at different average values of solar panels temperature.

\section{CONCLUSION}

The solar panels temperature do not remain constant for the whole daytime, but they change considerably. Investigations were done to represent the influence of the solar panels temperature variation on the performance of the optimized system. Several temperature data between $20^{\circ} \mathrm{C}$ and $50^{\circ} \mathrm{C}$ and solar radiation that intensity ranged $900<R_{S} \leq 1000$ $\mathrm{W} / \mathrm{m}^{2}$ were investigated. Output power represented in (current and voltage) and module efficiency were affected by the variations of solar panels temperature. It has been concluded that performance degraded once the temperature increases. The results showed that average voltage was $27.6 \mathrm{~V}$, average output power was $891.6 \mathrm{~W}$ and average module efficiency was $14.36 \%$ for the solar panels temperature average of $23.4^{\circ} \mathrm{C}$ at solar radiation average of $950.1 \mathrm{~W} / \mathrm{m}^{2}$. Average voltage was $27.3 \mathrm{~V}$, average output power was $868.7 \mathrm{~W}$ and average module efficiency was $14.13 \%$ for the solar panels temperature average of $34.6^{\circ} \mathrm{C}$ at solar radiation average of $941.1 \mathrm{~W} / \mathrm{m}^{2}$. Average voltage was $26.4 \mathrm{~V}$, average output power was 
870.2 $\mathrm{W}$ and average module efficiency was $14.16 \%$ for the solar panels temperature average of $45.0^{\circ} \mathrm{C}$ at solar radiation average of $940.1 \mathrm{~W} / \mathrm{m}^{2}$. Manufacturer mentioned that the change of voltage output for every solar panel temperature degree kelven was $(-0.35 \% \mathrm{~V} / \mathrm{K})$. From data equired from field measurments; it was $(-0.201 \% \mathrm{~V} / \mathrm{K})$ when solar panels temperature ranged from $\left(34.6^{\circ}\right.$ to $\left.45.0^{\circ} \mathrm{C}\right)$. On the otherhand, it was ($0.097 \% \mathrm{~V} / \mathrm{K})$ when solar panels temperature ranged from $\left(23.4^{\circ}\right.$ to $\left.34.6^{\circ} \mathrm{C}\right)$, and the change of output power for every solar panel tempereature degree kelven was $(-0.45 \% \mathrm{~W} / \mathrm{K})$. From data equired from field measurments; it was $(-0.111 \% \mathrm{~W} / \mathrm{K})$ when solar panels temperature ranged from (34.6 to $\left.45.0^{\circ} \mathrm{C}\right)$. On the otherhand, it was $(-0.229 \% \mathrm{~W} / \mathrm{K})$ when solar panels temperature ranged from $\left(23.4^{\circ}\right.$ to $\left.34.6^{\circ} \mathrm{C}\right)$, also Manufacturer mentioned that the module efficiency was $14.69 \%$. From data equired from field measurments; it was $14.36 \%$ at $23.4^{\circ} \mathrm{C}, 14.13 \%$ at $34.6^{\circ} \mathrm{C}$ and $14.16 \%$ at $45.0^{\circ} \mathrm{C}$.

\section{REFERENCES:}

Alonso G.M.C. and Balenzategui, J.L., (2004). Estimation of Photovoltaic Module Yearly Temperature and Performance Based on Nominal Operation Cell Temperature Calculations. Renewable Energy, 29:1997-2010.

Ebaid, M.S.Y.; Qandil, H. and Hammad, M., (2013). A Unified Approach for Designing a Photovoltaic Solar System for the Underground Water Pumping Well-34 at Disi aquifer. Energy Conversion and Management, 75:780-795.

Gouws, R. and Lukhwareni, T., (2012). Factors Influencing the Performance and Efficiency of Solar Water pumping Systems: a Review. International Journal of Physical Sciences, 7(48):61696180.

Hamrouni, N.; Jraidi, M. and Cherif, A., (2008). Solar Radiation and Ambient Temperature Effects on the Performance of a PV Pumping System, Revue des Energies Renouvelables, 11:95-106.

Nelson, J., (2003). The Physics of Solar Cells (Properties of Semiconductor Materials). Imperial College Press, London, 13-16 
Schwingshackla, C.; Petitta, M.; Wagner, J.E.; Belluardo, G.; Moser, D.; Castelli, M.; Zebisch, M. and Tetzlaff, A., (2013). Wind Effect on PV Module Temperature: Analysis of Different Techniques for an Accurate Estimation. Energy Procedia, 40:77-86.

Skoplaki, E. and Palyvos, J.A., (2009). On the Temperature Dependence of Photovoltaic Module Electrical Performance: A Review of Efficiency/Power Correlations. Solar Energy, 83:614-624.

\section{الملخص العربي}

تأثير الاشعاع الثمسي و درجة حرارة الوحدة الثمسية علي اداءهـا

إسراء فتحي الاحن، مبارك محمد مصطفى،

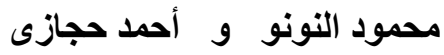

يتأثر اداء الخلايا الكهروضوئية بزيادة و نقصان درجة الحرارة و كذلك كثافة الاشعاع الثمسي. حيث ان الخلايا الكهروضوئية هى اشباه موصلات تزيد توصيليتها (فرق الجهد) بإنخفاض درجة درة درة حر ارتها. وجد ان درجة حرارة الخلية تلعب دورا كبيرا فى التأثير على الطاقة الكهربية المنتجة

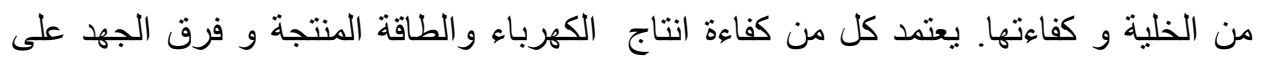
درجة حرارة الخلية الكهروضوئية وكذلك على نوعية الخلايا المستخدمة. و حيث الثة ان كفاءة الخلايا المستخدمة فى هذا البحث لانتاج الطاقة الازمة لادارة نظام الضخ تؤن تكون فى حدود

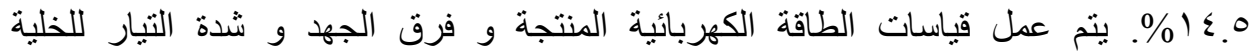

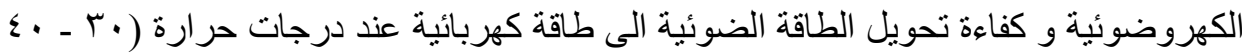

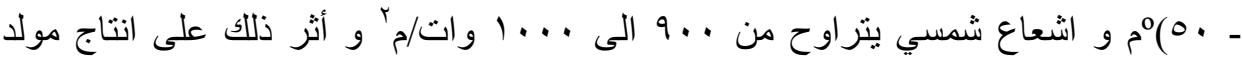

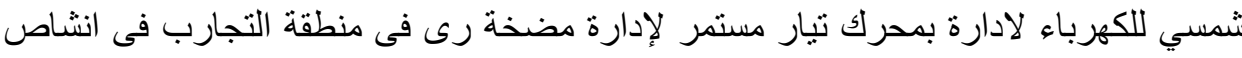

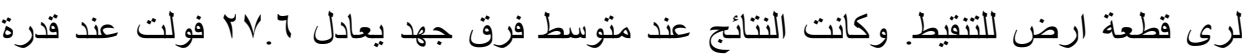

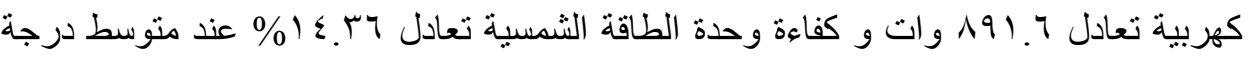

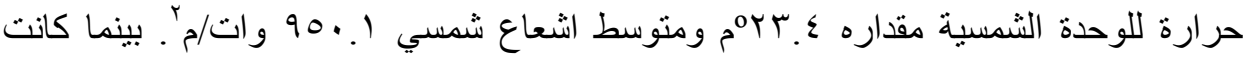

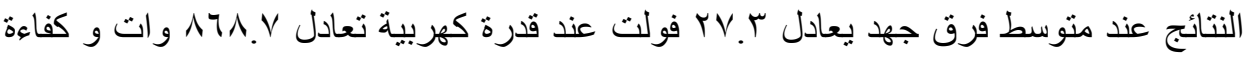

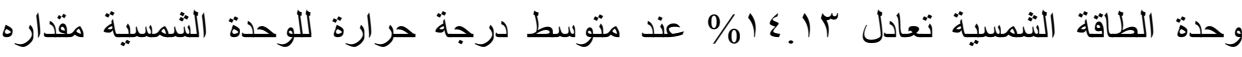

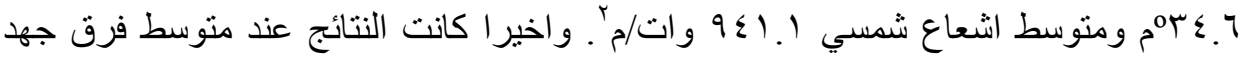

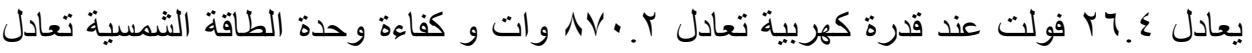

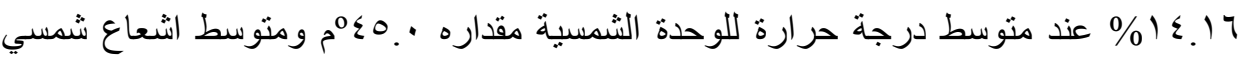

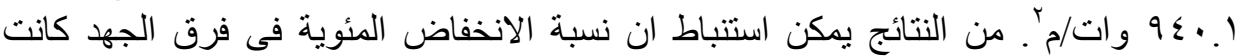

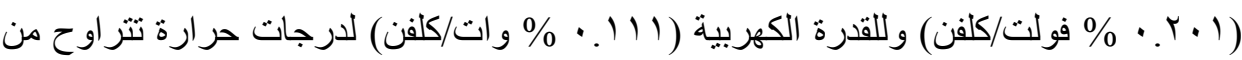

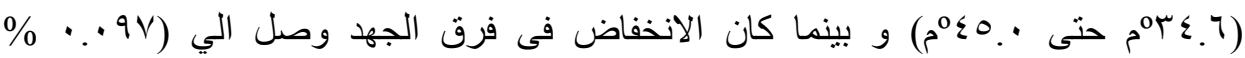

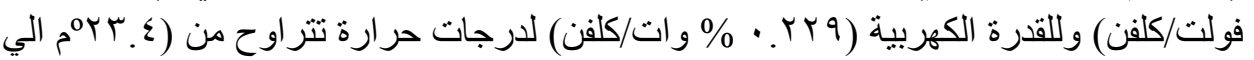
. ( ) 